\title{
Ação Popular Ambiental e Cidadania Solidária: a participação da população na gestão sustentável do meio ambiente e o modelo teórico do estado de direito ambiental
}

\author{
Janaína Rigo Santin ${ }^{1}$ \\ Thaís Dalla Corte ${ }^{2}$
}

Resumo: O meio ambiente é essencial para a vida. Entretanto, o modelo de exploração humano, mormente por razões econômicas, é predatório. Cada vez mais, a crise ecológica e os riscos sociais agravam-se. Nesse sentido, a tutela ambiental não pode ser evidenciada como tarefa exclusiva do Estado. O cidadão deve efetivamente participar na proteção do ambiente, inclusive por intermédio de instrumentos judiciais. Logo, a Ação Popular Ambiental apresenta-se como um importante mecanismo de defesa dos interesses difusos. Contudo, a cidadania ambiental ainda é incipiente. Com o escopo de promoção da consciência ambiental e do diálogo entre as gerações, por meio de valores solidários, discute-se o modelo teórico
Abstract: The environment is essential for life. However, the model of human exploration, mainly for economic reasons, is predatory. More and more, the ecological crisis and the social risks are growing. In this sense, the environmental protections can not be evidenced as exclusive task of the state. The citizen must effectively participate in environmental preservation, inclusively through judicial instruments. Therefore, the Popular Environmental Action is an important mechanism of defense of diffuses interests. Although, the environmental citizenship is insipient. With the objective of promoting environmental awareness and dialogue between generations, through solidarity values, this study discusses the theoretical model of the

1 Pós-Doutora em Direito pela Universidade de Lisboa. Doutora em Direito pela UFPR; Mestre em Direito pela UFSC; Advogada; Professora da Faculdade de Direito e do Mestrado em História da Universidade de Passo Fundo-RS. E-mail: janainars@upf.br.

2 Acadêmica do nono semestre do curso de Direito da Universidade de Passo Fundo e bolsista PIBIC/UPF. E-mail: tha_dallacorte@hotmail.com..

Recebido em: 06/04/2011.

Revisado em: 18/04/2011.

Aprovado em: 26/08/2011. 
do Estado de Direito Ambiental e o meio ambiente integrativo. Assim, visa-se estudar a Ação Popular Ambiental e a matriz solidária do Estado Ambiental, verificando os seus reflexos na participação judicial da população na gestão sustentável do ambiente.

Palavras-chave: Ação Popular Ambiental. Participação Popular. Estado de Direito Ambiental.
Environmental Rule of Law and the integrated environment. Thus, this research intent to analyze the Popular Environmental Action and the solidarity support of the Environmental Rule of Law, looking for the effects of the judicial participation of the population in the environmental management. The methodology is bibliographic, descriptive and exploratory.

Keywords: Popular Environmental Action. Popular Participation. Environmental Rule of Law.

\section{Considerações Iniciais}

A cada nova conquista humana, o mundo se modifica. Assim, com o passar dos anos a organização social evoluiu. Para justificar tal afirmação, basta um simples comparativo histórico dos primórdios da humanidade com o presente estágio de desenvolvimento da sociedade contemporânea. Essas transformações podem ser evidenciadas, principalmente, após a Revolução Industrial no Século XVII. A partir de então, o modelo de exploração dos recursos naturais se alterou: o paradigma sustentável deu espaço ao predatório. Dessa forma, o consumo dos bens com o objetivo precípuo de acumulação de capital, em decorrência do aumento da produtividade, tornou-se superior às capacidades do ambiente.

A alteração das bases econômicas, dos padrões de consumo e da tecnologia, conjuntamente com a falta de consciência ambiental - a qual começou a ganhar destaque somente a partir da Conferência das Nações Unidas sobre o Meio Ambiente Humano, realizada em 1972 em Estocolmo - dão origem à crise ambiental e, consequentemente, à sociedade de risco. Hodiernamente, os problemas ambientais são sentidos de forma empírica em esfera tanto global quanto local: mudanças climáticas, alteração da qualidade do ar, contaminação das águas e do solo, emissões de gás carbônico, redução da quantidade e da qualidade dos recursos naturais, métodos de exploração inadequados, perda da biodiversidade, entre outros. (CHACON, 2007).

Entretanto, não se pode afirmar que os efeitos das intervenções do homem no meio ambiente eram planejados. O ser humano sempre adap- 
tou o meio conforme as suas necessidades - afinal, o ambiente é elemento fundamental para a dinâmica da vida, nele se exteriorizando a relação entre o homem e a natureza. Até meados de 1980, o crescimento econômico pautou-se em uma racionalidade de curto prazo: desenvolvimento ilimitado da produção com base na inesgotabilidade dos recursos naturais do planeta. Portanto, graves impactos e riscos, até então desconhecidos historicamente, foram causados em decorrência da redução do bem ambiental diante dos valores de ordem econômica. (MARQUES, 2004, p. 174-175).

Nesse contexto, verifica-se que não há como dissociar o processo de desenvolvimento econômico da produção social de riscos. Quanto maior o desenvolvimento científico industrial, maiores são as gamas de problemas (por exemplo, danos ambientais) que se apresentam no meio. Para agravar tal situação, várias consequências dos riscos produzidos pela sociedade são desconhecidas pelo homem. Dessa forma, diuturnamente, os riscos ambientais acabam por não limitarem os seus efeitos apenas às presentes gerações: as futuras massas populacionais também serão expostas a eles, com resultados ainda mais graves. (DEMAJOROVIC, 2003, p. 35).

A sociedade de risco não surgiu de condutas intencionais humanas, nem mesmo escolheu-se fazer parte dela: é considerada um estágio da modernidade em que os efeitos da industrialização e suas ameaças começam a ganhar forma. Porém, com a evolução tecnológica, a percepção do risco se modificou - incrementam-se a ele as incertezas decorrentes do atual formato do processo de produção econômico. (BECK, 1997, p. 17). É cediço que não existe uma grandeza passível de mensurar os riscos que a sociedade encontra-se exposta. Contudo, excepcionalmente, há aqueles que podem ser controlados - conforme as experiências sociais já evidenciadas ou não. Por essa razão, as principais características do risco são: não se limitam no tempo e no espaço; há dificuldade de identificação do seu nexo causal; bem como as dificuldades de reparação e de compensação dos danos causados. (DEMAJOROVIC, 2003, p. 38-39).

Assim, conclui-se que é a partir da indefinição dos limites dos riscos e perigos produzidos pela sociedade, bem como pela falibilidade das medidas de segurança reconhecidas pelo organismo social que emerge as 
principais características da denominada sociedade de risco ${ }^{3}$. Consoante Beck (1997, p. 25), ela

[...] designa uma fase no desenvolvimento da sociedade moderna, em que os riscos sociais, políticos, econômicos e individuais tendem cada vez mais a escapar das instituições para o controle e a proteção da sociedade industrial.

É nesse contexto que a participação da população na gestão sustentável do meio ambiente deve ser pensada, uma vez que a sociedade de risco está intrinsecamente relacionada com a crise ambiental.

A administração sem sustentabilidade dos recursos naturais, o crescimento populacional desenfreado e a falta de conhecimento e consciência ambiental são os principais fatores da crise ecológica. O mais interessante é que o caos ambiental, principalmente nas últimas décadas do Século XX, tem os seus resultados majorados, inclusive pela conexão com outras crises (fenômeno denominado policrise), por exemplo, a do Subprimes (FERREIRA; LEITE, 2004, p. X). Como bem destaca Martins (2009), ao mesmo tempo em que no curto prazo a crise econômica tende a diminuir os efeitos malignos das ações humanas degradantes no meio ambiente (por exemplo, as emissões de dióxido de carbono), em longo prazo, possui a tendência de acarretar dificuldades e atrasos no desenvolvimento de políticas públicas ambientais, pela falta de investimentos.

Essas projeções já podem ser verificadas no planeta. A preocupação mundial encontra-se em restabelecer o crescimento econômico através de políticas monetárias e fiscais em detrimento à formulação de planos ambientais. Até mesmo as reuniões do G-20 em 2010 estavam pautadas em programas que visavam unicamente recuperar a vitalidade da economia global (G-20, 2010). O enfoque ambiental, assim, ficou em último plano. Verifica-se, dessa forma, que a organização social atual está baseada em

\footnotetext{
3 Nesse mesmo sentido, convém destacar o ensinamento de Ferreira (2004, p. 68): “A sociedade contemporânea tem início a partir do momento em que os riscos tornam-se incalculáveis e imprevisíveis e as instituições da sociedade industrial já não são capazes de controlar sua produção".
} 
uma irresponsabilidade organizada ${ }^{4}$. Os grandes grupos econômicos, ao desenvolverem métodos e mecanismos para reavivarem a economia, deveriam observar as diretrizes sustentáveis, sob pena de que, em poucos anos, outro grande colapso seja vivenciado: uma nova crise econômica (com efeitos mais graves) pela falta de matéria-prima.

Diante desse contexto depreende-se que os riscos sociais encontram-se em todo planeta. Contudo, diversamente dos séculos passados, as situações de risco atuais são diferentes das formas anteriormente conhecidas: são mais rápidos, intensos e de maior grau - assim como as mudanças realizadas pelo homem no meio ambiente ${ }^{5}$. Frente a esses problemas, para que a sustentabilidade ambiental torne-se realidade, é essencial a união de esforços entre a população e o Poder Público, em uma responsabilidade compartilhada de proteção do meio ambiente, inclusive, por intermédio de mecanismos processuais. Para tanto, verifica-se a necessidade de desenvolvimento da consciência ambiental e de especialização do modelo estatal.

É nesse sentido que o Estado de Direito Ambiental e a cidadania solidária vêm ganhando destaque nas pesquisas científicas e doutrinas mundiais, motivados, mormente, pela preocupação com a preservação ambiental para as futuras gerações. Assim, o Estado Democrático de Direito deve-se reestruturar, até mesmo porque é da sua natureza encontrar-se em constante processo evolutivo e dialético, com o objetivo de incorporar eficaz e permanentemente a tutela do meio ambiente (direito transindivi-

4 Nas palavras de Farias (2007, p. 4), conforme entendimento obtido de Ulrich Beck La sociedad del riesgo: hacia una nueva modernidad. Barcelona: Paidós, 2001, p. 38-39 - destaca que a irresponsabilidade organizada pode ser conceituada como "[...] a forma através da qual os sistemas políticos e econômicos dominantes procuram minorar a problemática dos riscos. Isso ocorre por meio da ocultação ou distorção das informações existentes ou simplesmente da aceitação dos riscos como um elemento natural e inevitável do processo de desenvolvimento econômico e científico". Complementa tal entendimento Leite e Belchior (2010, p. 294) quando afirmam que "[...] a irresponsabilidade organizada acaba transformando o Estado em faz-de-conta, em Estado fantoche, que só dá publicidade aos fatos científicos de acordo com seus interesses".

5 Segundo Ferreira (2004, p. 68-69), “[...] os riscos típicos da sociedade contemporânea são descritos como: ilimitados em função do tempo, globais no âmbito do seu alcance e potencialmente catastróficos". 
dual) de forma sustentável, participativa e solidária, em um modelo com novas dimensões político-jurídicas. (NUNES JUNIOR, 2004, p. 296-300)

Atualmente, variados são os instrumentos jurídicos existentes que têm o escopo de proteger o meio ambiente. Entre eles, destaca-se a Ação Popular Ambiental. Tal remédio constitucional permite a participação dos cidadãos na gestão sustentável do meio ambiente em decorrência da democracia ambiental. A partir da análise do Estado de Direito Ambiental percebe-se que a cidadania solidária aumenta os patamares e a esfera de atuação da população no gerenciamento ambiental. Dessa forma, tal ampliação tende a se refletir nos mecanismos jurídicos de tutela. Nesse sentido, a problemática da pesquisa é: a ação popular é um mecanismo jurisdicional de tutela subjetiva e participativa de proteção do meio ambiente, fundamentada na cidadania solidária do Estado de Direito Ambiental?

Logo, o presente estudo visa examinar a Ação Popular e o direito subjetivo dos cidadãos ao meio ambiente ecologicamente equilibrado. Objetiva relacionar esse mecanismo jurisdicional com a cidadania participativa e solidária do modelo teórico do Estado de Direito Ambiental, fundando o estudo, nesse contexto, nos valores da Constituição Federal de 1988 e nos princípios democráticos. O meio ambiente deve ser preservado e garantido não somente pelo Poder Público, mas por toda sociedade, a qual deve utilizar-se da Ação Popular Ambiental na tutela do meio ambiente, bem como deve agir de forma positiva, à luz do que dispõe a cidadania solidária do modelo teórico do Estado de Direito Ambiental.

\section{A Constituição Federal de 1988 e a Participação Popular na Gestão Ambiental}

Os impactos do homem no ambiente são determinados pelas suas necessidades vitais e sociais (cada qual em conformidade com o seu momento histórico). A maior parte das intervenções humanas motivadas pela falta de consciência ambiental e pela ambição não respeitaram (e, infelizmente, ainda não respeitam) os limites naturais. Para que a sociedade tivesse o seu crescimento compatível com o meio deveria adaptar-se à natureza. Contudo, percebe-se um paradoxo na organização política e 
social: o meio ambiente natural acaba tendo que se moldar às alterações realizadas pelo hominídeo. Justificam-se tais condutas em decorrência do modus vivendi adotado pela sociedade humana durante séculos - a supremacia dos valores econômicos em detrimento à preservação ambiental.

Em decorrência da visão antropocêntrica tradicional (o homem como o centro do universo e destinatário direto de todas as coisas), o modelo de exploração mercadista, na esfera jurídica, passou a ser compreendido sobre a vertente economicocentrista ou por meio do antropocentrismo alargado. Na visão economicocêntrica, os bens ambientais não são idealizados como recursos esgotáveis, pelo contrário, são reduzidos ao proveito econômico ilimitado. Ou seja, há uma submissão da natureza aos valores supremos da economia. Já, a linha antropocêntrica alargada visa à preservação ambiental - centrando a sua defesa sob a égide da garantia da dignidade da pessoa humana - uma vez que o ambiente passa a ser considerado autônomo como requisito elementar para a própria sobrevivência da humanidade. (LEITE, 2010, p. 157-158).

Ainda, na doutrina, em oposição ao antropocentrismo tradicional, difunde-se a teoria da ecologia profunda. Essa se fundamenta sob o argumento de que o homem e a natureza devem se integrar numa íntima relação. Busca-se uma nova compreensão do mundo na qual a natureza passa a ser sujeito de direito com dignidade própria. Inclusive, faz surgir novas categorias de direitos subjetivos como, por exemplo, a de animais e a de plantas (CANOTILHO, 2004, p. 4). No entanto, evidencia-se que tal corrente está encontrando dificuldades em se propagar, uma vez que o ser humano não consegue, ainda, desvencilhar-se do fato vinculado por séculos na sua cultura: o meio ambiente como um objeto servil à disposição das vontades humanas. Contudo, apesar das limitações com as quais a ecologia profunda se depara, sua importância é fundamental no

[...] aperfeiçoamento ético e filosófico da proteção jurídica do ambiente, bem como para um melhor entendimento da complexidade do significado de sistema ecológico. (LEITE, 2010, p. 159).

Assim, ao analisar a Constituição Federal de 1988, levando-se em consideração que o Direito tutelou por séculos o ambiente a partir da li- 
nha economicocentrista, percebe-se que a natureza não foi contemplada como simples instrumento para o desenvolvimento econômico e para acumulação de riquezas. Pelo contrário, a ordem constitucional econômica expressamente determina sua conformidade com a proteção ambiental. Logo, o texto constitucional adotou a teoria do antropocentrismo alargado, objetivando a sustentabilidade ambiental (LEITE, 2010, p. 160). Benjamin complementa o entendimento do citado autor, afirmando que o texto constitucional contempla a relação entre o ambiente e a economia além da visão antropocêntrica, mas também de forma biocêntrica (na questão da "preservação" encontrada no caput do artigo 225) e, até mesmo, de maneira ecocêntrica. (LEITE, 2010, p. 130).

Para tanto, basta uma análise do princípio geral da atividade econômica, a qual engloba a defesa do meio ambiente, consoante o artigo 170, inciso VI da Carta Magna. Ou seja, a livre iniciativa pode ser praticada desde que sejam observados os parâmetros constitucionais de preservação. Um exemplo disso é o $\$ 3^{\circ}$ do artigo 174 . Ele dispõe que as cooperativas de garimpeiros podem realizar suas atividades, mas, para tanto, devem tomar condutas de proteção do meio ambiente. Essa mesma leitura pode ser feita dos artigos 182 e 183 da Constituição que tratam da política urbana, bem como dos artigos 184 e 191 que expõem a política agrícola e fundiária. Ainda, merece realce o artigo 186 do diploma constitucional. Essa norma determina que a propriedade deve cumprir com a sua função socioambiental - assim, o aproveitamento econômico deve ser racional e adequado às capacidades suportáveis pelos recursos naturais, com vistas à preservação do meio ambiente (ANTUNES, 2004, p. 16).

Convém destacar que a relação entre o desenvolvimento econômico e o meio ambiente já vinha sendo objeto de preocupação brasileira mesmo antes do advento da Constituição de 1988. Para comprovar tal afirmação, basta uma análise da Lei n. 6.938, de 31 de agosto de 1981, a qual foi recepcionada no ordenamento jurídico e que dispõe sobre a Política Nacional do Meio Ambiente. Em seu artigo $4^{\circ}$, inciso I, verifica-se que o seu principal objetivo é a "[...] compatibilização do desenvolvimento econômico-social com a preservação da qualidade do meio ambiente e do 
equilíbrio ecológico"6. Dessa forma, a conciliação desses valores tem por escopo o desenvolvimento sustentável, que consiste

[...] na exploração equilibrada dos recursos naturais, nos limites da satisfação das necessidades e do bem-estar da presente geração, assim como de sua conservação no interesse das gerações futuras. (SILVA, 2003, p. 25-26).

O aspecto da proteção ambiental dentro da ordem econômica, no entanto, deve ser analisada - fundamentalmente - em conjunto com o artigo 225 da Constituição da República. Ao ambiente se estabelece uma visão ampliada, com unicidade e titularidade difusa, sendo considerado bem de uso comum do povo. Além do que lhe é conferido um status de bem abstrato e de valor intrínseco (LEITE, 2010, p. 160). Consoante Silva (2003) o meio ambiente deve ser entendido dentro do ordenamento jurídico brasileiro como "[...] a interação do conjunto de elementos naturais, artificiais e culturais que propiciem o desenvolvimento equilibrado da vida em todas as suas formas". Ou seja, o ambiente passa a ser concebido por meio de uma visão globalizada e integrada, como um macrobem ${ }^{7}$.

Assim, o artigo 225 da Carta Magna é o cerne de toda legislação ambiental. Segundo Feldmann e Camino (1992, p. 105), essa norma é reconhecida por ser "[...] uma síntese de todos os dispositivos ambientais que permeiam a Constituição". O entendimento dos autores fica claro quando se realiza uma análise da referida norma: ela determina a essencialidade do direito ao meio ambiente ecologicamente equilibrado para as presentes e futuras gerações. É de grande relevância o reconhecimento do meio ambiente como direito fundamental, pois passa a receber tratamento como valor primário, dotado de relevância imprescindível e com aplicação direta - ou seja, sem dependência de lei. Vale ressaltar que o direito ao meio ambiente equilibrado, no ordenamento jurídico brasileiro,

\footnotetext{
6 Merecem destaque, também, o artigo $2^{\circ}$ caput e incisos II, III, V, VI e VII da Lei n. 6.938/81 quanto à natureza econômica das normas de Direito Ambiental.

7 Convém destacar que, consoante Leite (2010, p. 222), apesar do bem ambiental ser considerado bem jurídico próprio e autônomo, sua proteção legal dá-se tanto na sua categoria de macrobem, quanto na de microbem (ou seja, naquilo que se relaciona aos seus elementos e componentes de forma isolada).
} 
é elevado à garantia fundamental, como uma subdivisão do princípio da dignidade de pessoa humana, mesmo não estando expresso no artigo $5^{\circ}$ da Constituição. (BENJAMIN, 2010. p. 118).

Ainda, extrai-se desse contexto que o artigo 225 é o sustentáculo da participação popular ambiental ${ }^{8}$, pois determina que a preservação do ambiente deve ocorrer por meio de uma responsabilidade conjunta entre o Poder Público e a sociedade. Segundo Burmann e Weschenfelder (2010, p. 39), existem três formas de participação popular ambiental: legislativa, administrativa e judicial. A legislativa compreende a participação na criação normativa do direito ambiental, sendo seus institutos a iniciativa popular de lei (CF, art. 14, inc. II), o plebiscito (CF, art. 14, inc. I) e o referendo (CF, art. 14, inc. II). Já, a administrativa engloba a participação na formulação e na execução de políticas ambientais por intermédio, por exemplo, das audiências públicas. E, por fim, a judicial que corresponde à participação via Poder Judiciário, exercida por meio da ação popular (CF, art. $5^{\circ}$, inc. XXXV) e da ação civil pública (CF, art. 129, inc. III e $\S 1^{\circ}$ ).

É por meio do princípio democrático - decorrente do artigo $1^{\mathrm{o}}$, parágrafo único da $\mathrm{CF} / 88$ - que a participação popular ambiental é assegurada. Nas palavras de Antunes (2004, p. 33), a participação da população nas políticas públicas de meio ambiente pode ocorrer de diversas maneiras. Em linhas gerais, o autor concorda com o entendimento supra exposto. No entanto, a sua classificação é diferente. Para ele, a participação popular ambiental pode ser dividida em: dever jurídico de proteger e preservar o ambiente, direito de opinar e mecanismos judiciais e administrativos. Assim, o dever jurídico corresponde às questões de ordem legislativa. Por sua vez, o direito de opinar relaciona-se às matérias administrativas acima demonstradas. Também, os mecanismos judiciais

8 Conforme Leite (2010, p. 186), a participação popular encontra os seus fundamentos no artigo $1^{\circ}$, parágrafo único, da Constituição Federal de 1988. É de tal dispositivo, inclusive, que se extrai o Princípio Democrático. No entanto, quando se trata especificamente de matéria de meio ambiente, o fundamento genérico da participação popular encontrase no artigo 225, caput, da Carta Magna. Ainda, vale ressaltar as palavras de Wolkmer (2003, p. 97) sobre a essencialidade da participação política popular: ela "[...] não só se revela importante mecanismo de atuação direta dos cidadãos no jogo democrático, como também a prática mais efetiva e permanente de controle da coisa pública". 
referem-se à Ação Popular e à Ação Civil. Não obstante, o autor inova ao trazer mecanismos administrativos na participação ambiental, elencando, entre eles, o direito de informação (CF, art. $5^{\circ}$, inc. XXIII), o direito de petição $\left(\mathrm{CF}\right.$, art. $5^{\circ}$, inc. XXIV) e o estudo prévio de impacto ambiental $\left(\mathrm{CF}\right.$, art. 225, inc. IV, $\left.\S 1^{\circ}\right)$.

Já, para Leite (2010, p. 187), o cidadão cumpre o seu dever de participar das questões relativas ao meio ambiente pelos seguintes meios: a participação na criação de direito ambiental; a formulação e execução de políticas ambientais; e o acesso ao Poder Judiciário. Portanto, verifica-se que não há diferença de posicionamento com o que já foi apresentado nesse estudo. No entanto, debates pontuais são trazidos pelo doutrinador quando afirma que a participação popular, por meio de abertura de processo legislativo com o escopo de criar normas ambientais, nos moldes do artigo 61 , caput, e $\S 2^{\circ}$ da CF/88, é de difícil concretização.

Consoante seu entendimento (LEITE, 2010, p. 187), a atuação da sociedade civil, por intermédio dos órgãos colegiados - os quais são dotados de poder normativo -, é mais eficiente do que a iniciativa de lei, devido à proximidade que se encontram da população, bem como pela facilidade no seu acesso. Assim, apesar dos enfoques de discussão sobre a efetividade da participação popular diante dos variados instrumentos que ela possui a sua disposição (essa discussão será desenvolvida pontualmente quanto à Ação Popular), resta evidente o formato inovador da unidade de cooperação que a democracia ambiental apresenta no ordenamento jurídico brasileiro.

Por sua vez, a partir da análise do artigo 225, caput, da Constituição de 1988, verifica-se que a democracia ambiental é disciplinada de forma abrangente. Ela não só determina uma responsabilidade compartilhada entre Poder Público, sociedade civil organizada e os cidadãos, mas também prevê uma responsabilidade social ambiental, a qual se consubstancia na obrigação com todas as gerações no uso racional e solidário dos recursos naturais. Fica claro, portanto, a preocupação constitucional com o meio ambiente ao determinar expressamente a reunião de esforços de 
todos os envolvidos ${ }^{9}$, a fim de que a gestão ambiental sustentável e a justiça social sejam concretizadas. (LEITE, 2010, p. 185).

Dessa forma, a democracia ambiental retira a competência exclusiva do ente estatal na tutela do meio ambiente. Tanto o Poder Público quanto os cidadãos possuem responsabilidades na esfera ambiental. Para os cidadãos, a responsabilidade consubstancia-se pelo binômio direito-dever: o direito do homem ao meio ambiente equilibrado e o seu dever de colaboração em busca da sustentabilidade ${ }^{10}$. Por isso, a coletividade deixa de ser mero espectador das decisões tomadas pelo Estado, passando a agir de forma ativa na formulação, execução e fiscalização das políticas públicas ambientais. Já o Estado tem o dever de elaborar normas que materializem a participação da população na tomada de decisões ambientais, bem como tem o escopo de desenvolver projetos, investimentos, e promover a educação ambiental, entre outros. (COSTA, 2007, p. 157-159).

Portanto, Derani (1997, p. 226-227) ressalta que há uma indissociabilidade do ente estatal e da sociedade, já que eles devem construir uma relação permanente por meio de um processo comunicativo e conjunto que envolva a "ação e a abstenção de ambos", tendo em vista um comportamento social positivo na gestão ambiental. É evidente que a população possui um papel de participação solidária e compartilhada na preservação do meio ambiente, a qual pode ser exercida por meio dos mecanismos judiciais de tutela do meio ambiente. A própria Carta Magna, entre os seus remédios constitucionais, estabeleceu um instrumento de proteção ambiental passível de ser exercido por qualquer cidadão: a Ação Popular.

\footnotetext{
9 Nesse contexto, convém destacar as importantes palavras de Wolkmer (2003, p. 98) quando afirma que "[...] trata-se de uma cidadania que não é mais "regulada" nem é concessão das elites ou do Estado. Rompe-se com o conceito liberal-burguês de cidadania (o indivíduo como titular de direitos eleitorais ou como aquisição de direitos legalmente concedidos) para figurála, criticamente, como conquista, construção, exercício cotidiano e prática social”.

10 Nas palavras de Costa (2007, p. 159): “Trata-se, portanto, de um poder-dever: a cidadania tem o direito (poder jurídico) de participação nas determinações relativas às questões ambientais (assegurado por meio de institutos da legislação infraconstitucional), mas tem também o dever de cooperar na tutela e manutenção da saúde ecológica do meio".
} 
A quase exaustão dos recursos naturais exigiu um novo tratamento, agora democrático, da questão ambiental. Dessa forma, para que a responsabilidade pelos danos ambientais seja apurada utilizam-se mecanismos processuais, que podem permitir a participação popular na tutela ambiental. Entre eles, destaca-se a Ação Popular Ambiental. Mas, há outros instrumentos que, quando comparados a Ação Popular Ambiental, são mais utilizados no cotidiano. São os casos da Ação Penal, do procedimento civil ordinário, da ação civil pública, do mandado de segurança coletivo, da tutela cautelar e da execução específica e mandamento cominatório. (SILVA, 2003, p. 318-326).

O objetivo central da criação da Ação Popular Ambiental foi " [...] tornar possível a efetivação da cidadania”. Em linhas gerais, ela dá margem para que todos os cidadãos sejam legitimados para anularem ou declararem nulos atos lesivos contra o meio ambiente - nesse caso, pois com a análise completa do artigo $5^{\circ}$, inc. LXXIII, da $\mathrm{CF} / 88$, verifica-se que esse mecanismo é dotado de diferentes objetos (proteção do erário, do patrimônio público, da moralidade administrativa, do meio ambiente e do patrimônio histórico e cultural). No entanto, a viabilidade prática da Ação Popular Ambiental encontra-se prejudicada. O maior obstáculo que tal instituto enfrenta é a democracia contemplativa ${ }^{11}$ (BARROS, 2008, p. 342), característica de um modelo de democracia liberal-burguês pautado apenas na representação.

A participação popular é prejudicada por uma cultura histórica de falta de consciência ambiental, bem como pela ausência de uma continuidade democrática na organização da política brasileira. Tudo isso faz com que os cidadãos pouco colaborem na gestão do meio ambiente. Essa situação é denominada pela doutrina como participação passiva, segundo a qual o homem age de forma conformista e alienada diante do meio am-

11 Pontua Wolkmer (2000, p. 95) que a democracia participativa delimita novos marcos à política: "[...] diante da crise da democracia representativa e da degeneração das relações da vida cotidiana, uma das direções possíveis para superar a exclusão e a marginalidade advém do poder de pressão dos novos sujeitos sociais, agentes capazes de instaurar uma prática política diferenciada e criativa. Esses novos sujeitos sociais que participam do processo histórico-social e modificam suas condições não têm nada a ver com os abstratos 'sujeitos individuais' da tradição liberal-burguesa". 
biente. Suas atitudes democráticas, portanto, se reduzem a contemplar as medidas adotadas pelo ente estatal. Logo, observa-se que grande parcela do povo não tem acesso a informações ambientais e nem mesmo aos instrumentos disponíveis para a sua preservação. Assim, muitas pessoas não agem em favor da tutela do meio ambiente por falta de conhecimento e interesse pela coisa pública (GOHN, 2001, p. 95). É nesse contexto que, cada vez mais, a educação e a consciência ambiental devem ser difundidas.

A partir do analisado, vale ressaltar que a participação popular ambiental não deve ser desvirtuada e vulgarizada. Nesse sentido, destaca Peruzzo $(1999$, p. 87) que, apesar da participação possuir caráter plural, isso “[...] não significa que todos tenham que tomar parte de tudo durante todo o tempo, o que, em termos de comunicação [e procedimentalmente], seria moroso, ineficiente e inviável [...]". Convém lembrar, contudo, que a ausência de participação popular ocasiona o enfraquecimento na tomada de decisões de matéria ambiental, acarretando o desenvolvimento de políticas e decisões díspares com os interesses sociais. Dessa forma, devem ser observadas medidas proporcionais e razoáveis nos mecanismos de participação popular ambiental, principalmente nos judiciais, sob pena de a preservação do meio ambiente não ser alcançada.

Visando motivar a democracia ambiental e a participação popular, a doutrina começa a dar maior destaque a Ação Popular como um mecanismo jurisdicional de controle dos atos degradatórios contra o meio ambiente. Conforme já analisado, em razão da constitucionalização da teoria antropocêntrica alargada, evidencia-se que a Carta Magna de 1988 adotou uma democracia ambiental baseada no compartilhamento de responsabilidades e solidariedade entre o Poder Público e a sociedade, bem como entre a presente e as futuras gerações. No entanto, apesar do incentivo legal, a participação judicial por meio da Ação Popular Ambiental ainda é fraca. Logo, a despeito da abrangência democrática do diploma constitucional, muitas medidas ainda devem ser realizadas a fim de que haja uma efetiva gestão ambiental popular. Nesse contexto, a Ação Popular Ambiental e a cidadania solidária do modelo teórico do Estado de Direito Ambiental, a qual amplia as esferas de proteção do meio ambiente, merecem análise cautelosa. 


\section{A Ação Popular Ambiental e a Cidadania Solidária do Estado de Direito Ambiental}

O ser humano identifica-se (e muitas vezes, confunde-se) com o meio ambiente. É a partir dessa íntima relação que os danos e impactos ambientais ocorrem. Os efeitos da intervenção antrópica inconsciente no meio deflagraram o atual estágio caótico da crise ambiental. Em busca de soluções e reversão dos danos causados ao ambiente, até mesmo porque se evidencia que a crise ecológica é um obstáculo ao contínuo crescimento econômico, a população começa a procurar meios de participar na gestão ambiental - de forma conjunta com o Poder Público - em busca da sustentabilidade. O sistema normativo brasileiro, nesse sentido, positivou a democracia social ambiental, almejando um novo pacto do homem com a natureza.

Dessa forma, percebe-se uma peculiaridade no Direito Constitucional Ambiental do Brasil: os instrumentos processuais de defesa do ambiente não possuem uma institucionalização pública ${ }^{12}$. Pelo contrário, em razão do meio ambiente ser considerado bem de uso comum (consoante a redação do artigo 225 da $\mathrm{CF} / 88$ ), ganha status de direito difuso. Assim, qualquer cidadão é parte legítima, individualmente, para exercer a tutela jurisdicional do meio ambiente. Essa legitimidade decorre do fato de que a preservação ambiental "é condição ao pleno desenvolvimento da personalidade humana". Logo, a Ação Popular apresenta-se no ordenamento jurídico como um direito de defesa subjetivo do meio ambiente. No entanto, a tutela não pode se pautar em um "[...] interesse exclusivamente individual próprio, mas sim atinente a um interesse coletivo ou difuso ambiental.” (LEITE, 2010, p. 221).

A questão do direito subjetivo ao meio ambiente deve ser tratada com certo cuidado para que o caráter unitário do ambiente - como bem

12 Segundo Dias (1997, p. 38-43), a Itália considera o meio ambiente como um bem público. Logo, os mecanismos judiciais de proteção do meio ambiente são de institucionalização pública, uma vez que, em razão da visão publicista, quaisquer danos praticados contra o meio ambiente são diretamente considerados lesões ao próprio ente estatal. 
jurídico - não seja desvirtuado. A titularidade individual de um direito subjetivo ambiental não significa que somente podem ser pleiteadas ações em juízo que se baseiam em interesses coletivos ou difusos, como é o caso da Ação Popular. Pelo contrário, existem tutelas de índole individualista que permitem postulações baseadas em interesses próprios. Inclusive, nas circunstâncias de indenizatórias para o ressarcimento de danos ambientais, um indivíduo, de maneira exclusiva, direta e pessoal, pode recebê-las em seu favor. Já, em se tratando da Ação Popular, o ressarcimento das lesões ocorre indiretamente em nome da coletividade, em razão do meio ambiente "[...] se tratar de um bem indivisível e de conotação social.” (LEITE, 2010, p. 224).

Dessa forma, aperfeiçoa-se a responsabilidade compartilhada e social entre o Poder Público e a coletividade na consecução de um meio ambiente ecologicamente equilibrado. Os atos das instâncias do poder ou dos próprios órgãos de poder são passíveis de controle externo por meio de intervenção direta do cidadão graças à democracia participativa presente na Ação Popular Ambiental (CANOTILHO; MOREIRA, 1993, p. 66). Ela pode ser conceituada como "[...] meio jurisdicional idôneo para defender, unido ao interesse pessoal, o interesse da coletividade referida a uma entidade pública: Nação, Estado ou Município." (BIELSA apud LEITE, 2000, p. 126). Dessa forma, objetiva-se, a partir da Ação Popular, a desconstituição de um ato lesivo, bem como a responsabilização - quer seja do Poder Público, quer seja de terceiros - para a reconstituição do bem ambiental ao seu estado anterior. Ainda, também, há possibilidade da condenação em perdas e danos (LEITE, 2000, p. 129-130).

A Ação Popular é um instituto muito antigo. Em Roma, a actio popularis já era um instrumento conhecido, em razão do interesse dos cidadãos em preservar a res publica. Na Idade Média, apesar de existente, era de pouca utilidade em razão da época feudal. Na Modernidade, primeiramente, a ação popular foi positivada na Lei Comunal de 1836 da Bélgica. Mais tarde, em 18 de julho de 1837, o mecanismo foi adotado pela França. Já, na Itália, as ações populares surgiram em 1859 vinculadas à matéria eleitoral. No Brasil, por sua vez, a ação popular tem uma longa história. Inicialmente, ela pôde ser encontrada na Constituição do Império (1824). No entanto, o instituto pouco se assemelhava com a sua atual for- 
ma. Nesse diploma, a ação popular visava apenas à repressão de abusos de poder e prevaricação que juízes e oficiais de justiça pudessem cometer no exercício de suas funções. Já, a Constituição da República (1891) não tratou da Ação Popular em seu texto. (BARROS, 2008, p. 341-342).

Somente com a Constituição de 1934, no artigo 113, inciso 38, o instituto começa a se moldar conforme os padrões hodiernos. Entretanto, a Constituição de 1937 suprimiu do ordenamento jurídico a ação popular, em decorrência do Estado Novo. Foi, então, com a Carta Magna de 1946, no artigo 141, §38, que o remédio constitucional voltou a ser previsto e teve a sua abrangência ampliada: a proteção dos atos lesivos não se reduziu somente aos praticados contra o patrimônio da União, dos Estados e dos Municípios. Passaram a receber tutela, também, as entidades autárquicas e sociedades de economia mista. Anos depois, em 29 de janeiro de 1965, entra em vigor a Lei n. 4.717 que veio regulamentar detalhadamente a Ação Popular. Com o advento da Constituição Federal de 1988, o texto da referida lei foi recepcionado. Portanto, continuam vigentes as suas disposições. Contudo, o artigo $1^{\circ}$ da Lei n. 4.717/65 - o qual é bem restritivo em razão da época e do contexto constitucional em que foi escrito - deve ser interpretado em conformidade com o que dispõe o artigo $5^{\circ}$, inciso LXXIII, da Carta de 1988. (BARROS, 2008, p. 341-342).

Convém destacar que a presente Carta Política objetivou estruturar a Ação Popular de forma a tornar efetiva a cidadania, aumentando os objetos passíveis de proteção. Foi, então, que surgiu, especificamente, a Ação Popular Ambiental, uma vez que o meio ambiente foi expressamente incluído entre os atos lesivos da administração pública ${ }^{13}$. Como destaca Souza (2004, p. 265), antes do advento da Constituição Federal de 1988, a doutrina e a jurisprudência já estavam admitindo a utilização da Ação Popular na tutela do meio ambiente em razão da Lei n. 6.513/77. Essa Lei passou a complementar o rol de proteção, incluindo, entre eles, os bens e direitos econômico, artístico, estético, histórico e turístico. Entendia-se, assim, que o meio ambiente encontrava-se englobado por esses valores, podendo ser protegido por meio da Ação Popular. Dessa forma, a Carta

13 Importante informação é trazida por Leite (2000, p. 130): a ação popular caracteriza-se "[...] como pioneira na tutela dos direitos de caráter coletivo lato sensu". 
Magna apenas ratificou em seu texto o que já estava sendo aplicado na prática.

Por fim, importa ressaltar que a Lei da Ação Civil Pública de n. 7.347/1985, em seu artigo primeiro, dispõe que “[...] regem-se pelas disposições desta lei, sem prejuízo da ação popular, as ações de responsabilidade por danos morais e patrimoniais causados: I- ao meio ambiente". Logo, a tutela do meio ambiente cabe tanto aos legitimados pela Ação Popular quanto aos legitimados pela Ação Civil Pública. Entretanto, Silva (2008, p. 277) alerta que o Ministério Público não possui legitimidade (assim como as pessoas jurídicas) na Ação Popular Ambiental, pois possui instrumento jurídico que lhe é próprio: a Ação Civil Pública ou o Mandado de Segurança Coletivo ${ }^{14}$

A Ação Popular, nesse sentido, tem o seu fundamento no artigo $5^{\circ}$, inciso LXXIII da Constituição Federal de $1988^{15}$. Segundo esse dispositivo, "qualquer cidadão é parte legítima para propor ação popular [...]". Esse é o requisito subjetivo da ação, também encontrado nos artigos $1^{\circ} \mathrm{e}$ $4^{\circ}$ da Lei n. 4.717/65. Assim, para um indivíduo ser considerado cidadão e, portanto, encontrar-se apto ao exercício da Ação Popular deve haver a concomitância de dois fatores indispensáveis: ser brasileiro (nato ou naturalizado) e eleitor (ou seja, estar no gozo dos direitos políticos, conforme o artigo 14, $\S 1^{\circ}$ da Constituição). Dessa forma, estrangeiros não teriam legitimação para agir. Tal fundamento pauta-se no fato de que a partir do

\footnotetext{
14 Fica claro que apenas o cidadão considerado individualmente ou em litisconsórcio com outros cidadãos-autores é apto à propositura da Ação Popular. Então, veda-se a atuação de ONGs, OSCIPs, sindicatos, partidos políticos, associações, fundações, entre outros. Consoante Leite (2000, p. 134), tal entendimento necessita ser revisado, pois “ “...] teoricamente as associações e as organizações de defesa ambiental estariam mais afetas aos problemas ecológicos e com maior representatividade no exercício da cidadania na demanda popular ambiental". No mesmo sentido, Wolkmer (2003, p. 98) afirma que “[...] o espaço político unificado e homogêneo das formas de representação convencional (partidos políticos e sindicatos) cede lugar à pluralidade de práticas participativas e atuações coletivas implementadas por novos sujeitos coletivos".

15 Leite (2000, p.131) explica que o dispositivo constitucional do artigo $5^{\circ}$, inciso LXXIII, não depende de norma regulamentadora (ou seja, é autoaplicável), pois “[...] as normas definidoras dos direitos e garantias fundamentais têm aplicação imediata [...]", em consonância com o que dispõe o artigo $5^{\circ}$, inciso LXXVII, $\S 1^{\circ}$.
} 
gozo dos direitos políticos surge para o cidadão a condição de físcalizar os representantes eleitos e os gestores da máquina estatal, com a finalidade de um gerenciamento eficiente e honesto da coisa pública (MANCUSO, 2003, p. 153-154). Logo, o diploma constitucional, ao estabelecer a dupla exigência, restringiu a capacidade processual no que tange à Ação Popular.

Entretanto, ao analisar a Ação Popular Ambiental verifica-se que, por tutelar bem jurídico de natureza difusa, não há o condicionamento do autor ao binômio brasileiro-eleitor para que seja dotado de legitimidade ativa. Ou seja, “[...] o regramento processual específico [...] exige a condição de eleitor ao cidadão para ajuizamento da Ação Popular da Lei 4.717/65. Não, entretanto, para o exercício da Ação Popular Ambiental." (SILVA, 2008, p. 276). Destaca Leite (2000, p. 133) que os pressupostos de legitimidade ativa do artigo $1^{\circ}$ da referida lei encontram-se "[...] em desconformidade com a lei fundamental, no que diz respeito ao estrangeiro residente no país e à defesa do bem ambiental popular".

Assim, em razão do artigo 225 da Constituição Federal estabelecer uma democracia social ambiental, pautada na participação e na responsabilidade compartilhada, qualquer indivíduo é parte legítima para propô-la. (LEITE, 2000, p. 132). A concepção de cidadão, nesse contexto, não está restrita a conotação política. Dessa forma, todos os brasileiros e estrangeiros ${ }^{16}$ - desde que residentes no País -encontram-se aptos a ajuizar Ação Popular Ambiental. (FIORILLO, 2005, p. 377). Nas palavras de Silva (2008, p. 276), o conceito de cidadão na Ação Popular Ambiental “[...] não está condicionado a ser concomitantemente eleitor, posto que não atua na defesa de direitos eminentemente políticos. Está na defesa de direito fundamental difuso, intimamente ligado ao direito à vida [...].” Assim, todos os que devem ter sua dignidade de pessoa humana respeitada possuem legitimidade ativa.

\footnotetext{
16 Para Leite (2000, p. 133), agiu muito bem “[...] o legislador constituinte, ao deferir ao estrangeiro residente no país o direito à ação popular fundamental, [pois] concedeu espaço a este para exercício de um direito subjetivo fundamental, intercomunitário, na proteção do meio ambiente".
} 
Complementa essa colocação Almeida (2003, p. 403) quando afirma que "[...] a concepção de cidadão deve ser extraída de um dos mandamentos nucleares da Constituição Federal, qual seja o princípio da dignidade da pessoa humana [...]". Logo, com fundamento no respeito de sua dignidade, podem ajuizar ação popular: “[...] o analfabeto que não se alistou, os maiores de 70 anos, cujo voto também é facultativo, os que não estejam em dia com o serviço eleitoral, os presos etc."

Nesse sentido, Souza (2004, p. 268) destaca que não se pode limitar o acesso à justiça, acrescentando que se deve admitir a propositura da Ação Popular Ambiental "[...] a todos que possam buscar a defesa dos valores fundamentais da sociedade". Complementa o doutrinador afirmando que, nesse contexto, até mesmo as pessoas jurídicas deveriam ter legitimidade de $\operatorname{agir}^{17}$. Na mesma linha, Moreira (1993, p. 189) sobressalta a importância de se repensar a legitimação, incluindo entre eles as pessoas jurídicas $^{18}$.

Outro requisito imprescindível para a propositura da ação popular é o objetivo. Consoante o artigo $5^{\circ}$, inciso LXXIII, segunda parte, da Constituição Federal de 1988, a Ação Popular visa

[...] anular ato lesivo ao patrimônio público ou de entidade de que o Estado participe, à moralidade administrativa, ao meio ambiente $\mathrm{e}$ ao patrimônio histórico e cultural [...].

Logo, nas palavras de Nishiyama (2004, p. 356-357), o propósito da ação é proteger o patrimônio público, invalidando os atos praticados com ilegalidade que causaram lesões a ele. Assim, destaca o autor, que além dos requisitos subjetivos e objetivo, existem dois pressupostos fundamentais para a propositura da ação popular: o ato ilegal e o ato lesivo ao patrimônio público. Ressalta que ambas as conjeturas obrigatoriamente devem se encontrar presentes. Logo, não é suficiente a presença isolada de uma

17 Porém, a contrário deste entendimento é a Súmula 365 do STF, a qual expressamente veda o direito às pessoas jurídicas de proporem Ação Popular.

18 Segundo Leite (2000, p. 133), na rota de rodapé n. 39, em 1980 tentou-se incluir como parte legítima para propor ação popular as pessoas jurídicas de direito privado. No entanto, tal proposta foi rejeitada. 
delas para sua procedência. Contudo, convém destacar que "[...] na maioria das vezes, a lesividade ao erário decorre da própria ilegalidade do ato praticado.” (NISHIYAMA, 2004, p. 356-357).

$\mathrm{Na}$ análise da ilegalidade do ato, destaca Mukai (2004, p. 109-111) que "[...] a ação popular não se presta para a plenitude da defesa ambiental, em termos de abrangência de todas as hipóteses de danos potenciais ou não ao meio ambiente". Em razão do requisito da legalidade, a Ação Popular torna-se possível somente nas atividades autorizadas pelo Poder Público. Ou seja, nas hipóteses de atos praticados por particulares que não possuam regulamentação ou disciplina legal pública, “[...] a defesa do meio ambiente deverá ser intentada através de outros meios processuais (ação ordinária, ação civil pública, em especial)". Assim, esse autor adota o critério da legalidade estrita, ao qual não se anula um ato porque ele é unicamente lesivo, mas sim porque é ilegal.

Em oposição ao entendimento acima exposto, ressalta Souza (2004, p. 269) que a partir da interpretação do texto constitucional, o qual expressamente enfoca a tutela do meio ambiente como um bem de todos, prevendo a possibilidade do cidadão utilizar-se da Ação Popular como mecanismo para anular ato lesivo ao meio ambiente, observa-se que não há referência do diploma sobre a exigibilidade do ato ser eivado de ilegalidade. Assim, segundo o referido autor, o ato "[...] pode ser legal e lesivo ao meio ambiente."19 Logo, pode-se ter uma atividade que seja "[...] licenciada pelo Poder Público, portanto, legal [...]”, mas que, ao mesmo tempo, se demonstre lesiva ao ambiente, ferindo, dessa forma, o direito à vida, que no ordenamento jurídico apresenta-se como direito fundamental de qualquer cidadão. Dessa forma, “[...] basta a presença da lesividade para justificar a propositura de uma ação popular”.

19 O entendimento de Souza (2004, p. 269) sobre a dissociabilidade dos pressupostos fundamentais para a propositura da ação popular ambiental é muito aceito na doutrina já que o meio ambiente possui natureza difusa. Assim, apesar dos diversos posicionamentos, segundo Mancuso (2003, p. 104), quando a demanda tiver natureza pública "[...] continuará sendo necessário que a causa de pedir na ação popular invoque o binômio ilegalidade-lesividade, mormente nos casos onde a procedência da ação (ou a concessão de liminar $-\S 4^{\circ}$ do artigo $5^{\circ}$ da Lei n. 4.717/65) venham a ter reflexos relevantíssimos na administração pública [...]". 
O posicionamento adotado, entre outros, por Souza é o que vem ganhando mais adeptos, pois tem por escopo colocar o meio ambiente em posição superior e privilegiar o desenvolvimento sustentável. Assim, não se configura a necessidade de que a causa de pedir fundamente-se nos requisitos da ilegalidade e da lesividade, uma vez que "[...] a demonstração de que o ato ou omissão lesou ou pode lesar o meio ambiente basta." (SILVA, 2008, p. 269). Consoante Leite (2000a, p. 166-167), em razão de a natureza ser bem difuso, ela não possui titular exclusivo e, portanto, é de responsabilidade solidária coletiva. Dessa forma, apenas há necessidade de se comprovar o ato lesivo, pois a prova da ilegalidade, às vezes, é praticamente impossível ${ }^{20}$. Para Milaré (2005, p. 990-991), “[...] a licitude da atividade não exclui a responsabilidade decorrente do dano ambiental". Resta evidente, nesse contexto, que a exigência simultânea da lesividade e da ilegalidade, no que se refere à Ação Popular Ambiental, acarretaria um sério obstáculo na gestão ambiental participativa.

Diante dessa discussão, Antunes (2005, p. 890) ressalta a tradicionalidade da Ação Popular como um mecanismo de defesa dos interesses difusos, uma vez que o autor popular age em nome próprio (legitimação ordinária $)^{21}$ na defesa do meio ambiente - bem jurídico coletivo. Destaca, ainda, que pessoas jurídicas, Ministério Público e associações encontram-se excluídas da legitimidade de ação. Contudo, acentua que o litiscon-

20 Nas palavras de Leite (2000, p. 139), a prova da ilegalidade pode ser muito complexa e de grande dificuldade, pois "[...] muitas lesões ambientais independem de um ato material do agente público e podem ser atos praticados diretamente pelo particular".

21 Convém destacar que esse posicionamento não é pacífico. Conforme Mazzili (1996, p. 97-98), quando o cidadão propõe ação popular, a sua legitimidade é extraordinária (substituto processual) na proteção do meio ambiente, uma vez que defende interesse que excede o âmbito da sua esfera pessoal. Em sentido contrário, Mancuso (2003, p. 163) afirma que “[...] a postura processual do autor popular não permite enquadrá-lo, exatamente, nos lindes da legitimação extraordinária, enquanto substituto processual”. Justifica tal posicionamento alegando que o meio ambiente é um direito difuso e, portanto, a tutela judicial do direito público subjetivo, com a finalidade de uma administração honesta e eficiente, gera, se procedente a ação, reflexos que beneficiam os demais cidadãos. Ainda, em razão de não existir vínculo jurídico entre o autor e os demais cidadãos, não se caracteriza o instituto da substituição processual, pois se permite que os outros cidadãos interessados ingressem em juízo como litisconsortes. Dessa forma, não há como o autor popular substituir os demais cidadãos, sendo a legitimidade ordinária. 
sórcio de cidadãos é plenamente possível na propositura de apenas um processo $^{22}$. Assim, na Ação Popular Ambiental considera-se o direito ao ambiente como subjetivo, pois pertence a cada um dos seres humanos. Segundo Leite (2010, p 221-222), esse direito subjetivo possui caráter solidário - “[...] e, não um perfil egoístico [...]" - pois além do cidadão ser beneficiário e destinatário das funções estatais no ambiente, torna-se seu efetivo guardião, defendendo o interesse tanto da legalidade quanto da coletividade, sem necessidade de comprovar seu "[...] interesse pessoal no ato lesivo ao meio ambiente".

Deve-se observar, todavia, que a ação popular possui nuances que a tornam de pouca utilização pela sociedade na defesa do meio ambiente. Conforme o artigo $5^{\circ}$, inciso LXXIII, terceira parte, da Constituição Federal de 1988, fica "[...] o autor, salvo comprovada má-fé, isento de custas judiciais e do ônus da sucumbência" ${ }^{23}$. No entanto, para a postulação em juízo há necessidade de advogado, devido à complexidade da ação, o que por vezes dificulta o acesso à justiça, quando não se facilita a figura do defensor público. Há Estados brasileiros, como Santa Catarina, que ainda não possuem esta carreira jurídica em seus quadros estaduais, contando apenas com a atuação dativa de advogados. ${ }^{24}$

A falta de consciência ambiental aliada ao desconhecimento da população de seus direitos e poderes participativos na gestão ambiental resulta em poucas Ações Populares Ambientais ajuizadas. Como destaca Souza (2004, p. 265), “[...] diante de abusos e desmandos praticados pela

22 Ressalta Silva (2008, p. 275) que o eventual litisconsórcio no polo passivo da Ação Popular Ambiental será facultativo (uma vez que não precisa ser ajuizada contra todos os agentes do ato impugnado - a responsabilidade é solidária) e simples, pois “[...] a sentença poderá conter comandos diferentes para as diversas partes envolvidas". Para Leite (2000, p. 135), na legitimidade passiva da Ação Popular Ambiental, a regra é "[...] de que todos que, de algum modo contribuírem para a lesão do bem ambiental, deverão compor o polo passivo. Esta regra incide tanto quando o objeto da proteção for o patrimônio público, estrito senso, como o bem difuso [...]", conforme o artigo $6^{\circ}$ da Lei n. 4.717/65.

23 Nas palavras de Leite (2000, p. 135), “[...] o legislador quis incentivar o exercício da cidadania da demanda popular, pois a isentou de custas processuais e ônus da sucumbência. Este incentivo facilita, de certa forma, o acesso à justiça, considerando outros obstáculos à tutela jurisdicional popular".

24 Ver: AGÊNCIA PARÁ, 2011. 
administração pública [...]”, principalmente nas épocas ditatoriais, a população acostumou-se a atuar de forma passiva na democracia ${ }^{25}$. Frente à alienação política e ao modelo econômico exploratório, a sociedade brasileira deixou de se indignar com os atos lesivos praticados contra o meio ambiente ${ }^{26}$. Dessa forma, a cidadania ambiental, presente na Constituição de 1988, deve ser efetivada e desenvolvida no âmbito da educação formal e informal, a fim de que tais problemas possam ser superados.

A cidadania ambiental compreende um

[...] conjunto de direitos e garantias das responsabilidades atribuídas tanto ao Poder Público como à sociedade civil (cidadãos organizados ou não), dotados da capacidade de perseguir e fazer valer seus direitos ambientais [...] (COSTA, 2007, p 159).

Para tanto, ressalta-se o papel da Ação Popular Ambiental, cujos fundamentos estão contidos tanto no artigo 225 da Magna Carta, como já eram antes verificados na Lei n. 6.938/1981 que, no artigo $2^{\circ}$, inciso VII, estabelece a promoção da "[...] educação ambiental a todos os níveis do ensino, inclusive a educação da comunidade, objetivando capacitá-la para a participação ativa na defesa do meio ambiente". Esse é o princípio da participação popular na tutela ambiental, reafirmado na Declaração do Rio (1992 $)^{27}$ buscou reafirmar tal posicionamento, em razão da sua importância.

25 Segundo Souza (2004, p. 265), “[...] a ação popular é a ferramenta processual que permite ao cidadão retratar a indignação, através do exercício pleno de um direito subjetivo público. Diante da perda da capacidade de se indignar, esse cidadão, que na maioria das vezes é indiferente, não se sente motivado ou encorajado a usar esse importante direito público".

${ }^{26}$ Muito relevante a constatação de Leite (2000, p. 134): “[...] muitas vezes a insignificância do dano causado às pessoas individualmente consideradas, a falta de consciência ambiental, os obstáculos e a lentidão do acesso à justiça, temor de enfrentar demandados economicamente poderosos, e outras ponderações, podem afastar o lesado a individualmente tutelar os interesses coletivos, lato sensu".

27 A Declaração do Rio sobre Meio Ambiente e Desenvolvimento surgiu a partir da Conferência das Nações Unidas sobre Meio Ambiente e Desenvolvimento, que ocorreu no Rio de Janeiro, de 3 a 14 de junho de 1992. Ela é considerada como um dos diplomas ambientais mais importantes dentro da legislação do meio ambiente. Assim, em 
Logo, a participação popular na proteção do meio ambiente ampliou as perspectivas políticas do povo na gestão sustentável graças à cidadania ambiental. Evidencia-se, assim, um dever de responsabilidade solidária entre o Estado e a coletividade: o Poder Público, de forma geral, possui a obrigação de defender e preservar o ambiente; já, os cidadãos apresentam o encargo de maneira particular, almejando a proteção global atual e futura. São a partir das ações positivas e conjuntas de todos os envolvidos que se extrai a essência da cidadania ambiental. Entretanto, diante dos problemas acima expostos, ela possui pouca efetividade, a qual se reflete na incipiente postulação popular na defesa do meio ambiente. Assim, visando dar maior ênfase à tutela do ambiente, desenvolve-se na doutrina o modelo teórico do Estado de Direito Ambiental ${ }^{28}$.

Segundo Nunes Junior (2004, p. 295), “o papel do Estado” está se reequacionando na sociedade. Nesse sentido, destaca Leite (2000, p. 124) que, a partir da crise ambiental e frente ao retrato de uma sociedade de risco, começa-se a discutir a necessidade de reformas na estrutura estatal, a fim de que a "racionalidade do capital", tanto social quanto ecológica, que resulta em "degradação ambiental e prejuízo à coletividade", seja revista $^{29}$. Surge, então, o paradigma do Estado de Direito Ambiental, uma vez que se reconhece que "[...] o direito ao meio ambiente equilibrado é a luz de todos os direitos fundamentais e da existência de uma nova ordem pública ambiental." (LEITE; BELCHIOR, 2010, p. 299).

consonância com o Princípio n. 10: “A melhor maneira de tratar questões ambientais é assegurar a participação, no nível apropriado, de todos os cidadãos interessados. No nível nacional, cada indivíduo terá acesso adequado às informações relativas ao meio ambiente de que disponham as autoridades públicas, inclusive informações acerca de materiais e atividades perigosas em suas comunidades, bem como a oportunidade de participar dos processos decisórios. Os Estados irão facilitar e estimular a conscientização e a participação popular, colocando as informações à disposição de todos. Será proporcionado o acesso efetivo a mecanismos judiciais e administrativos, inclusive no que se refere à compensação e reparação de danos".

28 Esse paradigma estatal, segundo Leite e Belchior (2010, p. 299-300), foi defendido, precipuamente, sob a denominação de Estado Constitucional Ecológico pelo germânico Rudolf Steinberg, na obra Der Ökologische Verfassungsstaat.

29 Para Leite (2000, p. 123), deve-se levar em consideração que “[...] tanto o modelo capitalista como o coletivista marginalizaram a questão social ambiental". 
Convém destacar que tal (re)formulação no modelo estatal não tem por escopo destruir as bases ostentadas pelo Estado Democrático de Direito. Pelo contrário, esse paradigma busca agregar novas qualidades à organização social. Como bem destaca Canotilho, “[...] além de ser um Estado de Direito, um Estado Democrático e um Estado Social, deve também modelar-se como Estado Ambiental." (1995, p. 22). Então, o propósito maior desse conjunto, com medidas fundamentadas nos valores ambientais, é a proteção do meio ambiente em busca do desenvolvimento sustentável e duradouro, a partir dos alicerces já existentes no mundo político-jurídico. Para tanto, conforme os dizeres de Nunes Junior (2004, p. 299), faz-se necessário que “[...] muitos institutos jurídicos (preexistentes) sejam renovados e muitos institutos jurídicos (novos) sejam criados dentro do ordenamento".

A estrutura ambiental destaca-se pelo tratamento especial e cuidadoso despendido à natureza - considerado valor intrínseco do poder organizativo - visando à proteção dos riscos ambientais. Ou seja, há uma ampliação dos objetivos estatais, o qual deixa de tutelar apenas os perigos lesivos ao meio ambiente e passa a proteger os riscos, sejam eles iminentes ou potenciais, de dano ambiental, numa real "gestão responsabilizada dos riscos" ${ }^{\prime 30}$. (LEITE; BELCHIOR, 2010, p. 301). É sob essa égide que o Estado de Direito Ambiental busca viabilizar o bem-estar da sociedade com justiça social ${ }^{31}$. No entanto, para sua efetivação, é primordial o desenvolvimento de uma cidadania solidária ${ }^{32}$, com plena consciência ambiental, para o exercício da responsabilidade compartilhada e da participação popular.

${ }^{30}$ Nas palavras de Leite e Belchior (2010, p. 301), esse modelo não tem por objetivo a figura do Estado-herói, ou seja, aquele que tem por escopo a eliminação total do risco. Pelo contrário, segundo Leite e Ferreira (2009, p.438) quer-se o desenvolvimento de “[...] formas mais adequadas para a gestão dos riscos e evitar a irresponsabilidade organizada". 31 Convém destacar, segundo Marques (2004, p. 180), que a justiça ambiental deve indicar o rumo da reforma do Estado. Para tanto, “[...] a sociedade política deve orientar os seus esforços no sentido de levar a coletividade a preservar aquilo que existe e recuperar aquilo que deixou de existir".

32 Nas palavras de Canotilho (2004, p. 8), a democracia ecológica - sustentada e autossustentável - visa a "[...] reabilitação da democracia dos antigos como democracia de participação e de vivência da virtude ambiental". 
Sob a ótica de Canotilho (2004, p. 08-13), verificam-se vários pressupostos fundamentais no desenvolvimento do Estado Ambiental: a concepção integrada do meio ambiente, a institucionalização dos deveres fundamentais ambientais e o agir integrativo da administração. No presente estudo, enfocar-se-á, apenas, a concepção integrada ou integrativa do ambiente, pois a proteção global e sistêmica - não reduzida

[...] à defesa isolada dos componentes ambientais naturais (ar, luz, água, solo vivo e subsolo, flora, fauna) ou dos componentes humanos (paisagem, património natural e construído, poluição) [...]

- produz consequências no modo de atuação dos instrumentos jurídicos ${ }^{33}$ do Estado de Direito Ambiental (CANOTILHO, 2004, p 8-9). Logo, a demanda popular ambiental é essencial para a edificação de um Estado pautado na vertente ecológica. Nessa lógica, o fundamento teórico-jurídico mais destacado do paradigma ambiental é o princípio da solidariedade ${ }^{34}$.

A solidariedade, no Estado de Direito Ambiental, apresenta-se de forma ampla, "( [...] perpassando a esfera individualista própria do Estado Liberal).” (NÚNES JUNIOR, 2003, p. 300). Dessa forma, a proteção ambiental demanda um novo relacionamento entre a presente e as futuras gerações, a fim de que os "encargos e responsabilidades na equidade geracional" sejam divididos. Ao se analisar o artigo 225 da Constituição Federal de 1988 verifica-se que o Brasil possui condições de "recepcionar o novo modelo de Estado", uma vez que há fundamentação constitucional ambiental que, inclusive, com realce, trata da solidariedade ao "impor ao Poder Público e à coletividade o dever de proteger o meio ambiente" para a atual e para a população que há de vir. Ainda, o próprio artigo $3^{\circ}$, inciso

33 Complementa Leite e Belchior (2010, p. 302) que a partir de um olhar integrativo do bem ambiental, há a promoção de redundantes modificações "[...] na forma como os instrumentos jurídicos são concebidos, definidos e implementados pelo Estado”.

34 Os princípios fundantes do Estado de Direito Ambiental são o da solidariedade, da legitimidade e o da juridicidade. Já, os que dão estrutura ao modelo, nas palavras de Leite e Belchior (2010, p. 304-305), são “[...] o da precaução, o da prevenção, o da responsabilização, do poluidor-pagador, da participação, da cidadania, o princípio da democracia, o princípio da informação, o princípio da proibição do retrocesso ecológico e o princípio do mínimo existencial ecológico". 
I, da Magna Carta prevê, entre os objetivos da República, “a construção de uma sociedade livre, justa e solidária.” (LEITE; BELCHIOR, 2010, p. 305-306).

Nesse contexto, evidencia-se que a democracia ambiental brasileira segue os moldes da cidadania ecológica do modelo-teórico do Estado de Direito Ambiental ${ }^{35}$. No entanto, urge a necessidade de colocar os seus pressupostos em prática, bem como especializar a democracia para a senda solidária. É evidente a responsabilidade compartilhada entre Poder Público, cidadãos e sociedade civil organizada na tutela ambiental. Tal responsabilidade compartilhada e comum apresenta-se de suprema importância em razão da essência e da difusidade do bem ambiental. Apenas com a reunião de esforços de todos os envolvidos é que a gestão sustentável se concretizará. Ademais, "[...] todo problema de política ambiental só poderá ser resolvido quando reconhecida a unidade entre os cidadãos." (LEITE, 2003, p. 35).

Mais especificamente sobre a cidadania solidária, convém destacar que dois são os pressupostos da democracia ambiental visando à solidariedade: acesso a informações ${ }^{36}$ e consciência ambiental. Aliada à participação popular, a transparência no exercício democrático (por intermédio de informações claras à sociedade) dá origem a decisões ambientais em conformidade com os anseios sociais, viabilizando a tomada de consciência da importância do meio ambiente ${ }^{37}$. Portanto, afasta-se a irresponsabilidade organizada. Assim, evidencia-se que a solidariedade do Estado de Direito Ambiental amplia as esferas de atuação do cidadão em várias

\footnotetext{
35 Até mesmo, pois - como destaca Leite (2003, p. 35) - “[...] para se edificar e estruturar um abstrato Estado Ambiental, pressupõe-se uma democracia ambiental". (grifo do autor).

36 Consoante Canotilho (1995, p. 32), o Estado Ambiental caracteriza-se pela abertura da democracia política, “[...] em que os cidadãos têm o direito de obter dos poderes públicos informações sobre o estado do ambiente".

37 Convém ressaltar o entendimento de Leite (2010, p. 185-186) sobre a ilegitimidade do Poder Público no Estado de Direito Ambiental. Para o autor, essa se consubstancia quando há uma atuação unilateral do ente estatal, sendo negada a coletividade o acesso a informações. Dessa forma, descaracteriza-se o due process ambiental, entrando em cena, então, a tomada de decisões apenas centrada em interesses parciais, ferindo o direito difuso da coletividade a um meio ambiente equilibrado.
} 
áreas. Nesse paradigma, incentiva-se que o sistema legislativo viabilize a participação da coletividade nas decisões ambientais, bem como que a sociedade emita suas opiniões e tenha amplo acesso a informações no desenvolvimento de políticas públicas e nos mecanismos judiciais de defesa do meio ambiente ${ }^{38}$. (LEITE, 2010, p. 184).

Logo, a base da cidadania solidária do Estado de Direito Ambiental é a necessidade de cooperação entre todos: Estados, sociedade civil organizada e população. $\mathrm{O}$ bem ambiental ganha ainda mais relevo de bem da coletividade e de interesse público. Veda-se, dessa forma, o uso irracional, autoritário e indiscriminado de seus recursos, quer seja pelo Poder Público, quer seja por um particular. Assim, a gestão e a administração do meio ambiente devem ser compartilhadas e solidárias. Para tanto, devem se fundamentar na cidadania ambiental presente no ordenamento jurídico brasileiro. A partir da incorporação permanente e gradual dos valores solidários do Estado de Direito Ambiental, reflexamente, a população vai se encontrar mais atuante e postulante na proteção do meio ambiente. Dessa forma, faz-se necessário repensar a Ação Popular Ambiental, cada vez mais, para que a participação da população na gestão sustentável do meio ambiente, por intermédio de mecanismos judiciais, seja cidadã, participativa, responsável, solidária e, acima de tudo, efetiva.

\section{Conclusões}

Diante do exposto, verifica-se que o homem e o meio ambiente encontram-se em permanente interação. Por ser um bem difuso, o ambiente acaba sendo destinatário direto de todos os efeitos das condutas humanas. Infortunadamente, as ações antropogênicas não consideraram (e ainda não consideram) tal relação. Para tanto, basta analisar a história. Com o advento da Revolução Industrial, sentiram-se as primeiras consequências da crise ecológica causada pela exploração superior às capacidades

38 Nas palavras de Leite e Belchior (2010, p. 307), convém destacar que a solidariedade apresenta-se como "[...] um grande desafio aos juristas [...]", especialmente pela necessidade de relacionamento entre as gerações. O tema torna-se complexo, "[...] pois não se sabe o que está por vir". Logo, ainda muitos estudos fazem-se necessários para que a solidariedade se realize em toda a sua amplitude. 
do meio ambiente. Com o passar dos anos, essas causas, riscos e alcances agravaram-se, sendo perceptíveis empiricamente.

Atualmente, essa crise, a qual se encontra em estágio avançado, tem os seus resultados majorados pela conexão com outras crises como, por exemplo, a do Subprimes. A busca do reaquecimento da economia de forma desestruturada e predatória faz surgir o pesar de um colapso ambiental-econômico mais grave, em decorrência da falta de recursos naturais e de matéria-prima. Evidencia-se, assim, que há uma tensão dialética permanente entre a proteção ambiental e o desenvolvimento econômico.

É preciso alertar que a organização social deve desenvolver-se pautada em novos valores, capazes de equilibrar economia e meio ambiente. É nesse sentido que a Constituição Federal de 1988 adotou a teoria do antropocentrismo alargado, e que a partir disso discutem-se teorias sobre a ecologização do Estado.

O Estado de Direito Ambiental é um modelo teórico que surge diante do caos ambiental, da sociedade de risco e da irresponsabilidade organizada. Fundado sobre a matriz solidária, esse paradigma caracteriza-se por suas dimensões jurídicas regerem-se por princípios ecológicos, sendo a sua orientação densificada pelas diretrizes sustentáveis. A partir de seus pressupostos - concepção integrada do meio ambiente, institucionalização dos deveres fundamentais ambientais e agir integrativo da administração - o presente estudo analisou o meio ambiente integrativo, com vistas à ampliação da tutela jurisdicional ambiental por intermédio da cidadania solidária.

Dessa forma, analisando o artigo 225 da Constituição Federal de 1988 verifica-se que o ordenamento jurídico brasileiro tem potencial de Estado de Direito Ambiental, mormente em razão do status fundamental conferido ao direito ao meio ambiente equilibrado. A democracia ambiental e a participação popular - elementos necessários para a edificação do Estado Ambiental - encontram-se fortemente reguladas na Magna Carta, e reafirmados na Declaração do Rio de 1992. Por sua vez, a abrangência participativa reflete-se nos mecanismos judiciais de defesa do meio ambiente. Nesse contexto, o artigo destaca a Ação Popular Ambiental, um remédio constitucional capaz de dar maior abertura democrática para os 
cidadãos, por meio de um direito subjetivo fundamental de caráter difuso e de postulação individual.

Durante séculos, as tradições históricas brasileiras e o costume popular reproduziram (e, infelizmente, ainda reproduzem), valores autoritários, dominantes e de alienação política, o que desafia o desenvolvimento de uma democracia participativa, sustentável, contumaz e significativa. Esse conjunto de fatores reflete-se nas ainda incipientes Ações Populares Ambientais. Nesse contexto, a cidadania solidária do Estado de Direito Ambiental, por meio do acesso a informações, da promoção da consciência ambiental e do diálogo entre as gerações, amplia as esferas de atuação do cidadão, seja no desenvolvimento de políticas públicas, de leis ou na proteção judicial ambiental. Tais condições, aliadas às responsabilidades compartilhada, comum e social, potencializam uma cidadania mais ativa, capaz de racionalizar as necessidades do meio para sua sobrevivência e das gerações futuras.

Nesse sentido, verifica-se que a Ação Popular é um mecanismo jurisdicional de tutela subjetiva e participativa de proteção do meio ambiente. No entanto, apesar da abrangência da cidadania ambiental da Magna Carta, muitos obstáculos devem ser transpostos para que a solidariedade do Estado de Direito Ambiental - em especial pela dificuldade de não se conhecer o que ainda encontraremos pela frente - seja efetivada por meio da Ação Popular.

Os moldes e fundamentos solidários do modelo teórico ambiental, apesar de não serem utilizados, já se verificam em nosso ordenamento jurídico. Logo, é a partir das bases existentes e com a colaboração de outros instrumentos, como a hermenêutica jurídica, que a participação da população na gestão sustentável do meio ambiente, por intermédio de mecanismos judiciais, será efetiva, buscando-se, cada vez mais, a solidariedade do Estado de Direito Ambiental e o aperfeiçoamento da Ação Popular Ambiental. 


\section{Referências}

AGÊNCIA Pará. Movimento pró-defensoria pública realiza encontro em Santa Catarina. 5 de abril de 2011. Disponível em: $<$ http://www. agenciapara.com.br/noticia.asp?id_ver=74982 >. Acesso em: 6 abr. 2011. ALMEIDA, Gregório Assagra de. Direito processual civil coletivo: um novo ramo do direito processual. São Paulo: Saraiva, 2003.

ANTUNES, Paulo de Bessa. Direito ambiental. 7. ed. rev., atual. e ampl. Rio de Janeiro: Lumen Juris, 2005.

BARROS, Wellington Pacheco. Direito ambiental sistematizado. Porto Alegre: Livraria do Advogado, 2008.

BECK, Ulrich. A reinvenção da política: rumo a uma teoria da modernização reflexiva. In: BECK, Ulrich; GIDDENS, Anthony; LASH, Scott. Modernização reflexiva: política, tradição e estética na ordem social moderna. São Paulo: UNESP, 1997.

BENJAMIN, Antônio Herman. Direito constitucional ambiental brasileiro. In: CANOTILHO, José Joaquim Gomes; LEITE, José Rubens Morato (Org.). Direito constitucional ambiental brasileiro. 3. ed. rev. São Paulo: Saraiva, 2010.

BRASIL. Constituição, 1988. Constituição da República Federativa do Brasil de 5 de outubro de 1988. Disponível em: <www.soleis.adv.br/ leispornome.htm>. Acesso em: 13 jan. 2011.

BRASIL. Supremo Tribunal Federal. Súmula n. 365. Disponível em: $<$ http://www.stf.jus.br/portal/cms/verTexto.asp?servico=jurisprudenciaSu mula\&pagina=sumula_301_400>. Acesso em: 17 jan. 2011.

BRASIL. Lei Federal n. 6.938, de 31 de agosto de 1981. Disponível em: <http://www.planalto.gov.br/ccivil_03/Leis/L6938.htm>. Acesso em: 17 jan. 2011.

BRASIL. Lei Federal n. 4.717, de 27 de agosto de 1962. Disponível em: $<$ http://www.planalto.gov.br/ccivil/leis/L4117.htm>. Acesso em: 18 jan. 2011. 
BURMANN, Larissa Lauda; WESCHENFELDER, Paulo Natalício. A educação e a informação como condições para o exercício da participação popular ambiental. In: FIORILLLO, Celso Antonio Pacheco (Coord.). Revista Brasileira de Direito Ambiental, São Paulo, v. 21, n. 6, p. 33-53, jan./mar. 2010.

CANOTILHO, José Joaquim Gomes. Direito público do ambiente. Coimbra: Faculdade de Direito de Coimbra, 1995.

. Estado Constitucional Ecológico e Democracia Sustentada. In: FERREIRA, Heline Sivini; LEITE, José Rubens Morato (Coord.). Estado de direito ambiental: tendências - aspectos constitucionais e diagnósticos. Rio de Janeiro: Forense Universitária, 2004.

CANOTILHO, José Joaquim Gomes; MOREIRA, Vital. Constituição da República Portuguesa anotada. Coimbra: Coimbra Edições, 1993.

CHACON, Suely Salgueiro. Reflexões sobre a crise ambiental: uma viagem até suas origens. Disponível em: $<$ http://www.cofecon.org.br/ index.php?option $=$ com_content $\&$ task $=$ view $\& i d=796 \&$ Itemid $=51>$. Acesso em: 11 jan. 2011.

COSTA, Melina de Oliveira Gonçalves Fernández. A ação popular como instrumento de defesa do meio ambiente e exercício da cidadania ambiental. Revista Direito Público, Brasília, v. 1, n. 15, p. 148-168, jan./ mar. 2007.

DEMAJOROVIC, Jacques. Sociedade de risco e responsabilidade socioambiental: perspectivas para a educação corporativa. São Paulo: Senac, 2003.

DERANI, Cristiane. Direito ambiental econômico. São Paulo: Max Limonad, 1997.

DIAS, José Eduardo de Oliveira Figueiredo. Tutela ambiental e contencioso administrativo. Coimbra: Coimbra Edições, 1997.

FARIAS, Talden Queiroz. Considerações a respeito da injusta distribuição do dano e do risco ambiental no espaço social. Revista Jurídica Direito e Liberdade/ Escola da Magistratura do Rio Grande do Norte, Mossoró, v. 7, n. 3, p. 411-425, 2007. 
FELDAMANN, Fábio José; CAMINO, Maria Ester Mena Barret. O direito ambiental: da teoria à prática. Revista Forense, Rio de Janeiro, v. 317, 1992.

FERREIRA, Heline Sivini. O risco ecológico e o princípio da precaução. In: FERREIRA, Heline Sivini; LEITE, José Rubens Morato (Coord.). Estado de direito ambiental: tendências - aspectos constitucionais e diagnósticos. Rio de Janeiro: Forense Universitária, 2004.

FERREIRA, Heline Sivini; LEITE, José Rubens Morato (Coord.). Estado de direito ambiental: tendências - aspectos constitucionais e diagnósticos. Rio de Janeiro: Forense Universitária, 2004.

FIORILLO, Celso Antonio Pacheco. Curso de direito ambiental brasileiro. 6. ed. São Paulo: Saraiva, 2005.

G-20. Publications. [2010]. Disponível em: <http://www.g20.org/pub_ index.aspx>. Acesso em: 6 nov. 2010.

GOHN, Maria da Glória. Conselhos gestores e participação sociopolítica. São Paulo: Cortez, 2001.

LEITE, José Rubens Morato. Dano ambiental: do individual ao coletivo extrapatrimonial. São Paulo: RT, 2000a.

LEITE, José Rubens Morato. Ação popular: um exercício da cidadania ambiental? RDA, ano 5, n. 17. São Paulo: RT, jan./mar. 2000 b.

LEITE, José Rubens Morato. Dano ambiental: do individual ao coletivo extrapatrimonial. 2. ed. rev., atual. e ampl. São Paulo: RT, 2003.

LEITE, José Rubens Morato. Sociedade de risco e Estado. In: CANOTILHO, José Joaquim Gomes; LEITE, José Rubens Morato (Org.). Direito constitucional ambiental brasileiro. 3. ed. rev. São Paulo: Saraiva, 2010.

LEITE, José Rubens Morato; BELCHIOR, Germana Parente Neiva. O Estado de Direito Ambiental e a particularidade de uma hermenêutica jurídica. Revista Seqüência, Florianópolis, n. 60, p. 291-318, jul. 2010. 
LEITE, José Rubens Morato; FERREIRA, Maria Leonor Paes Cavalcanti. As novas funções do direito administrativo em face do Estado de Direito Ambiental. In: CARLIN, Volnei Ivo (Org.). Grandes temas de direito administrativo: homenagem ao professor Paulo Henrique Biasi. Campinas: Millenium, 2009.

MANCUSO, Rodolfo de Camargo. Ação popular: Proteção do erário, do patrimônio público, da moralidade administrativa e do meio ambiente. 5 . ed. rev., atual. e ampl. São Paulo: Ed. RT, 2003.

MARQUES, Angélica Bauer. A cidadania ambiental e a construção do Estado de Direito do Meio Ambiente. In: FERREIRA, Heline Sivini; LEITE, José Rubens Morato (Coord.). Estado de direito ambiental: tendências - aspectos constitucionais e diagnósticos. Rio de Janeiro: Forense Universitária, 2004.

MARTINS, Artaet Arantes da Costa. A crise mundial e o meio ambiente. [2011?]. Disponível em: <http://neomondo.org.br/index. php?option $=$ com_content $\&$ view $=$ article $\&$ id $=328$ :a-crise-mundial-e-omeio-ambiente\&catid=87:artigos\&Itemid=89> . Acesso em: 12 jan. 2011 .

MAZZILLI, Hugo Nigro. A defesa dos interesses difusos em juízo. 8. ed. São Paulo: Saraiva, 1996.

MIRALÉ, Édis. Direito do ambiente: doutrina, jurisprudência, glossário. 4. ed. rev., atual. e ampl. São Paulo: RT, 2005.

MOREIRA, José Carlos Barbosa. Ação Civil Pública. Revista Trimestral de Direito Público, São Paulo, n. 3, 1993.

MUKAI, Toshio. Direito ambiental sistematizado. 4. ed. Rio de Janeiro: Forense Universitária, 2004.

NISHIYAMA, Adolfo Mamoru. Remédios constitucionais. São Paulo: Manole, 2004.

NUNES JUNIOR, Amandino Teixeira. O estado ambiental de direito. Revista de Informação Legislativa, Brasília, n. 163, v. 41, p. 295-307, jul./set., 2004. 
NUNES JÚNIOR, Venilto Paulo. O conceito de soberania no século XXI. Revista de Direito Constitucional e Internacional, São Paulo, n. 42, ano 11, jan./mar. 2003.

ONU. Declaração do Rio sobre meio ambiente e desenvolvimento. [2011?]. Disponível em: <http://www.mma.gov.br/sitio/index. php?ido $=$ conteudo. monta\&idEstrutura $=18 \&$ idConteudo $=576>$. Acesso em: 12 jan. 2011.

PERUZZO, Cicilia Maria Krohling. Comunicação nos movimentos populares: a participação na construção da cidadania. 2. ed. Petrópolis: Vozes, 1999.

SILVA, Flávia Regina Ribeiro da Silva. Ação popular ambiental. São Paulo: RT, 2008.

SILVA, José Afonso da. Direito constitucional ambiental. 4. ed. São Paulo: Malheiros, 2003.

SOUZA, Paulo Roberto Pereira de. A tutela jurisdicional do meio ambiente e seu grau de eficácia. In: LEITE, José Rubens Morato; DANTAS, Marcelo Buzaglo (Org.). Aspectos processuais do direito ambiental. 2. ed. Rio de Janeiro: Forense Universitária, 2004.

WOLKMER, Antonio Carlos. Ideologia, estado e direito. 4. ed. rev., atual. e ampl. São Paulo: RT, 2003. 